\title{
Pengembangan Permainan Scrabble Kimia Sebagai Media Pembelajaran Pada Materi Termokimia Kelas XI SMA/MA
}

\section{Development of Chemistry Scrabble Game as Learning Media in Thermochemistry Material for Class XI SMA/MA}

\author{
S Humaira ${ }^{1}$ and F Azra ${ }^{1 *}$ \\ 1 Pendidikan Kimia, Universitas Negeri Padang, \\ Jl. Prof. Dr. Hamka, Air Tawar Barat, Padang Utara, Sumatera Barat, Indonesia 25171 \\ *bunda_syasfa@yahoo.com
}

ARTICLE INFO

Received on:

25 August 2020

Revised till:

11 December 2020

Accepted on:

12 December 2020

Publisher version published on:

28 February 2021

\begin{abstract}
The chemical scrabble game is a variety of learning media in doing practices. This type of research is Research and Development $(R \& D)$ with a 4-D model. This research is up to the developing stage with validity and practicality tests. The instrument used was a validity and practicality questionnaire. The validity test was carried out by five validators, while the practicality test was carried out by two chemistry teachers and 20 class XII students. The data analysis techniques used were the Aiken's $V$ formula and descriptive statistics. The results of the data analysis show that the chemical scrabble media has a validity of 0.81 showing a valid category, the practicality of the teacher is $89.93 \%$ belonging to a very practical category and the practicality of students is $83.80 \%$ belonging to a very practical category, so that the availability of the developed thermochemical scrabble game chemicals can be used as a medium of learning.
\end{abstract}

\section{KEYWORDS}

4-D Model, Chemistry Scrabble, R\&D, Thermochemistry

\section{ABSTRAK}

Permainan scrabble kimia merupakan salah satu variasi media pembelajaran dalam mengerjakan latihan. Jenis penelitian ini yaitu Research and Development (R\&D) dengan model 4-D. Penelitian ini dibatasi sampai tahap develop dengan uji validitas dan praktikalitas. Instrumen yang digunakan berupa angket validitas dan praktikalitas. Uji validitas dilakukan oleh lima orang validator, sedangkan uji praktikalitas oleh dua orang guru kimia dan 20 orang peserta didik kelas XII. Teknik analisis data menggunakan formula Aiken's V dan statistik deskriptif. Hasil analisis data menunjukkan media scrabble kimia memiliki validitas 0,81 dengan kategori valid, praktikalitas guru $89,93 \%$ dengan kategori sangat praktis serta praktikalitas peserta didik $83,80 \%$ dengan kategori sangat praktis, sehingga disimpulkan permainan scrabble kimia materi termokimia yang dikembangkan dapat digunakan sebagai media pembelajaran.

KATA KUNCI

Model 4-D, Scrabble Kimia, R\&D, Termokimia 


\section{PENDAHULUAN}

Termokimia merupakan salah satu materi dalam pembelajaran kimia kelas XI IPA SMA/ MA. Materi termokimia berisi pengetahuan faktual, prosedural, dan konseptual. Materi termokimia mencakup perubahan entalpi suatu reaksi, persamaan termokimia, konsep sistem dan lingkungan, reaksi endoterm dan eksoterm, perubahan entalpi standar (entalpi pembentukan, pembakaran, dan penguraian), kalorimeter, hukum hess, serta energi ikatan. Kurikulum 2013 menuntut peserta didik untuk terlibat aktif dalam kegiatan pembelajaran. Guru berperan sebagai fasilitator yang harus mampu menciptakan suasana belajar yang menyenangkan, hal ini dapat dibantu dengan penggunaan media pembelajaran.

Hasil pengisian angket oleh guru dan peserta didik di SMAN 5, SMAN 10, dan SMAN 16 Padang menyatakan bahwa guru telah menggunakan media pembelajaran berupa buku cetak, PPT, LKPD, serta video pembelajaran. Peserta didik dalam proses pemantapan konsep diberikan contoh soal serta latihan setelah proses pembelajaran. Latihan pada pembelajaran kimia di ketiga sekolah tersebut cenderung diberikan secara individu dalam bentuk objektif dan esai yang bersumber dari buku cetak, LKPD, dan buku kumpulan soal.

Latihan diberikan untuk memantapkan konsep, mendorong motivasi belajar, dan mengembangkan kemampuan berpikir dari peserta didik untuk menyelesaikan masalah mengenai materi yang dipelajari ${ }^{[1]}$. Pemberian latihan secara berulang-ulang dapat meningkatkan penguasaan peserta didik terhadap suatu materi pembelajaran ${ }^{[2]}$. Aktivitas peserta didik dalam mengerjakan latihan di SMAN 5 Padang, SMAN 10 Padang, dan SMAN 16 Padang masih rendah. Hasil observasi menyatakan bahwa $58,76 \%$ peserta didik kurang senang ketika diminta untuk mengerjakan latihan secara individu oleh guru, hal ini disebabkan karena latihan yang diberikan guru belum sesuai dengan karakteristik peserta didik yang senang bekerja dalam kelompok dan menyukai permainan. Pernyataan ini didukung oleh pendapat ${ }^{[3]}$ bahwa kekhasan tingkah laku sosial remaja salah satunya yaitu berkelompok dan bermain. Sehingga dalam hal ini diperlukan suatu alternatif agar semua peserta didik dapat terlibat aktif dan merasa senang dalam mengerjakan latihan.

Metode yang menyenangkan dalam proses pembelajaran salah satunya adalah metode yang mengombinasikan antara hiburan dan pendidikan. Metode ini dikenal dengan istilah edutainment. Edutainment merupakan salah satu bentuk improvisasi dalam kegiatan pembelajaran dengan cara membuat pembelajaran menjadi menyenangkan ${ }^{[4]}$. Salah satu bentuk metode edutainment ialah penggunaan permainan dalam kegiatan belajar-mengajar.

Permainan merupakan salah satu media pembelajaran yang bisa menarik minat belajar dan sesuai dengan karakteristik peserta didik.
Permainan yang digunakan dalam kegiatan belajar mengajar akan memberikan dampak pada keaktifan dan interaksi peserta didik di dalam kelas ${ }^{[5]}$. Hasil observasi di ketiga sekolah tersebut menyatakan bahwa guru belum pernah menggunakan permainan sebagai variasi latihan. Guru dan peserta didik tertarik menggunakan permainan sebagai salah satu variasi latihan pada proses pembelajaran kimia.

Variasi media pembelajaran dalam proses pemantapan konsep yang dikembangkan yaitu permainan scrabble kimia. Permainan scrabble merupakan permainan menyusun huruf menjadi suatu kata. Media permainan menyusun kata seperti scrabble dapat memberikan motivasi dan tantangan kepada peserta didik ${ }^{[6]}$. Media pembelajaran ini diharapkan dapat membuat peserta didik menjadi lebih aktif dalam mengerjakan latihan. Permainan scrabble kimia yang dikembangkan mempunyai perbedaan dengan permainan scrabble pada umumnya. Pada permainan ini, Pemain menyusun kata sesuai dengan kata kunci yang telah tersedia yang berhubungan dengan materi termokimia. Selanjutnya pemain yang telah menyusun kata, maka harus menjawab pertanyaan yang terdapat pada kartu soal sesuai dengan kata yang dapat tersusun.

\section{METODE}

Jenis penelitian pada penelitian ini adalah Research and Development (R\&D). Research and Development (R\&D) merupakan suatu metode penelitian dengan tujuan untuk menciptakan sebuah produk serta menguji keefektifan dari produk yang dihasilkan ${ }^{[7]}$. Model pengembangan yang digunakan yaitu model $4-\mathrm{D}$ yang memiliki empat tahapan utama yakni tahap define, design, develop, dan disseminate. Akan tetapi, penelitian ini terbatas sampai tahap develop dengan melakukan uji validitas dan praktikalitas media. Subjek dalam penelitian ini yaitu dua orang dosen kimia FMIPA UNP, tiga orang guru kimia SMA/MA, dan 20 peserta didik kelas XII.

Tahap define bertujuan untuk menetapkan dan mendefinisikan syarat-syarat dari suatu pembelajaran ${ }^{[8]}$. Tahap define memiliki lima tahapan yakni: (a) analisis ujung depan; (b) analisis peserta didik; (c) analisis tugas; (d) analisis konsep; (e) perumusan tujuan pembelajaran. Tahap design bertujuan untuk merancang media pembelajaran yang relevan dengan data yang didapatkan dari tahap define. Tahap develop bertujuan untuk memperoleh suatu media pembelajaran yang valid dan praktis untuk digunakan dalam proses belajarmengajar. Instrumen pada penelitian ini berupa angket validasi dan praktikalitas. Angket validasi diberikan kepada dosen dan guru kimia, sedangkan angket praktikalitas diberikan kepada guru kimia dan peserta didik.

Data yang didapatkan dari angket validitas selanjutnya dianalisis dengan formula Aiken's V, yang ditunjukkan pada Persamaan 1 dan Persamaan 2, dimana $\mathrm{r}$ adalah skor kategori pilihan validator; $\mathrm{n}$ adalah jumlah validator; lo adalah angka 
penilaian validitas yang terendah; serta c adalah angka penilaian validitas yang tertinggi. Di akhir pengolahan tersebut diperoleh nilai $\mathrm{V}$ atau disebut dengan indeks kesepakatan validator.

$$
\begin{gathered}
V=\frac{\Sigma s}{[n(c-1)]} \ldots \text { Persamaan } 1 \\
\mathrm{~s}=\mathrm{r}-\text { lo } \ldots \text { Persamaan } 2
\end{gathered}
$$

Tingkat validitas media menggunakan formula Aiken's $\mathrm{V}$ dapat ditentukan dengan melihat tingkat kategorinya yang disajikan pada Tabel 1 .

Tabel 1. Kategorivaliditas berdasarkan skala Aiken's V ${ }^{[9]}$.

\begin{tabular}{c|c} 
Skala Aiken's V & Validitas \\
\hline $\mathrm{V} \leqslant 0,4$ & Kurang \\
\hline $0,4<\mathrm{V} \leqslant 0,8$ & Sedang \\
\hline $0,8<\mathrm{V}$ & Valid
\end{tabular}

Data yang didapatkan dari angket praktikalitas kemudian dianalisis dengan menggunakan statistik deskriptif, dengan Persamaan 3, dimana $\mathrm{P}$ adalah praktikalitas produk; $\mathrm{f}$ adalah nilai total yang diperoleh dari angket; serta $\mathrm{N}$ adalah nilai maksimum pada angket.

$$
P=\frac{f}{N} \times 100 \% \ldots \text { Persamaan } 3
$$

Tingkat praktikalitas media menggunakan statistik deskriptif dapat ditentukan dengan melihat kategori kepraktisan yang disajikan pada Tabel 2 .

Tabel 2. Kategori Kepraktisan ${ }^{[10]}$.

\begin{tabular}{c|c} 
Skor & Kriteria \\
\hline $80 \%<x \leqslant 100 \%$ & Sangat Praktis \\
\hline $60 \%<x \leqslant 80 \%$ & Praktis \\
\hline $40 \%<x \leqslant 60 \%$ & Cukup Praktis \\
\hline $20 \%<x \leqslant 40 \%$ & Kurang Praktis \\
\hline $0 \%<x \leqslant 20 \%$ & Tidak Praktis
\end{tabular}

\section{HASIL DAN DISKUSI}

\subsection{Tahap Define (Pendefinisian)}

\subsubsection{Analisis Ujung Depan}

Analisis ujung depan dilakukan dengan penyebaran angket kepada guru dan peserta didik di SMAN 5, SMAN 10, dan SMAN 16 Padang. Hasil rekap angket menyatakan bahwa bahan ajar yang digunakan dalam kegiatan belajar-mengajar kimia di sekolah yaitu buku cetak, LKPD, powerpoint, dan video pembelajaran. Latihan yang diberikan guru cenderung bersifat individu dan bersumber dari buku cetak, LKPD, dan buku kumpulan soal. Hasil rekap angket juga menyatakan bahwa aktivitas peserta didik dalam mengerjakan latihan rendah, hal ini dapat disebabkan karena latihan yang diberikan guru belum sesuai dengan karakteristik peserta didik yang suka bekerja dalam kelompok, senang berdiskusi, dan menyukai permainan. Oleh karena itu, diperlukan media pembelajaran yang menyenangkan dan dapat meningkatkan aktivitas peserta didik dalam mengerjakan latihan. Media tersebut dapat berupa media permainan. Berdasarkan hal tersebut, maka dikembangkan media pembelajaran berupa permainan scrabble kimia.

\subsubsection{Analisis Peserta Didik}

Analisis peserta didik dilakukan dengan cara pengisian angket oleh guru dan peserta didik. Hasil rekap angket menyatakan bahwa peserta didik di SMAN 1, SMAN 5, dan SMAN 16 Padang suka bekerja dalam kelompok dan menyukai permainan. Hasil rekap angket juga menyatakan bahwa peserta didik tertarik dengan permainan scrabble kimia yang disarankan.

\subsubsection{Analisis Tugas}

Analisis tugas dilakukan dengan menganalisis kurikulum 2013 revisi 2018 sesuai dengan Permendikbud No 37 tahun 2018 tentang Kompetensi Inti (KI) dan Kompetensi Dasar (KD) pada materi termokimia dan menjabarkannya dalam bentuk indikator - indikator pencapaian kompetensi. Kompetensi Dasar pada materi termokimia yaitu KD 3.4 dan 3.5.

\subsubsection{Analisis Konsep}

Konsep utama pada materi termokimia yaitu energi, lingkungan, sistem, sistem terbuka, sistem tertutup, sistem terisolasi, kalor, kerja, perubahan entalpi reaksi, perubahan entalpi pembentukan, pembakaran, dan penguraian standar, perubahan energi dalam, energi pembentukan standar, kalorimeter, hukum hess, energi ikat, reaksi eksoterm, dan reaksi endoterm.

\subsubsection{Perumusan Tujuan Pembelajaran}

Tujuan pembelajaran pada materi termokimia dirumuskan sebagai berikut: "Melalui permainan scrabble kimia sebagai media pembelajaran alternatif dalam memberikan latihan untuk memantapkan konsep, diharapkan peserta didik dapat mengerjakan latihan dalam permainan secara aktif, menyenangkan, dan mampu menjawab soal yang berhubungan dengan perubahan entalpi suatu reaksi pada tekanan tetap, konsep sistem dan lingkungan, reaksi eksoterm dan endoterm pada tekanan tetap, persamaan termokimia, jenis perubahan entalpi standar (entalpi pembentukan, penguraian, dan pembakaran), hukum hess dan energi ikatan.

\subsection{Tahap Design (Perencanaan)}

Media pembelajaran berupa permainan scrabble kimia pada materi termokimia yang akan dikembangkan dirancang pada tahap define. Satu set permainan scrabble kimia terdiri dari kimia terdiri dari papan permainan, kepingan huruf, rak kepingan, daftar kata kunci, kartu soal, kartu kunci jawaban, 
dan kartu penilaian. Perlengkapan permainan scrabble kimia ini dikemas dalam satu kotak.

\subsubsection{Papan Permainan scrabble Kimia}

Papan permainan scrabble kimia dibuat dengan menggunakan aplikasi Corel Draw A7 dan dicetak pada spanduk berukuran A2. Papan permainan scrabble kimia terdiri atas 361 kotak dan dilengkapi dengan gambar dan konsep yang berhubungan dengan materi termokimia. Bagian sebelah kanan dilengkapi dengan aturan permainan serta tabel periodik unsur yang berhubungan dengan pedoman penskoran. Papan permainan scrabble kimia disajikan pada Gambar 1 .

\subsubsection{Kartu Soal dan Kartu Jawaban Permainan Scrabble Kimia}

Permainan scrabble kimia dilengkapi dengan adanya kartu soal serta kartu jawaban. Permainan ini memiliki 25 butir soal berbentuk pilihan ganda. Penulisan soal disesuaikan dengan Kompetensi Dasar (KD) dan Indikator Pencapaian Kompetensi (IPK) yang harus dicapai pada materi termokimia. Kartu soal dan kartu jawaban disajikan pada Gambar 2.

\subsubsection{Kepingan Huruf, Rak Kepingan, dan Kantong Kepingan}

Kepingan huruf permainan scrabble kimia terbuat dari potongan kayu kecil berukuran $2 \mathrm{~cm}$ x $2 \mathrm{~cm}$ x 0,2 cm. Jumlah kepingan huruf pada permainan scrabble kimia yaitu 220 kepingan dengan 200 kepingan berisi huruf dan 20 kepingan kosong. Kepingan huruf permainan scrabble kimia

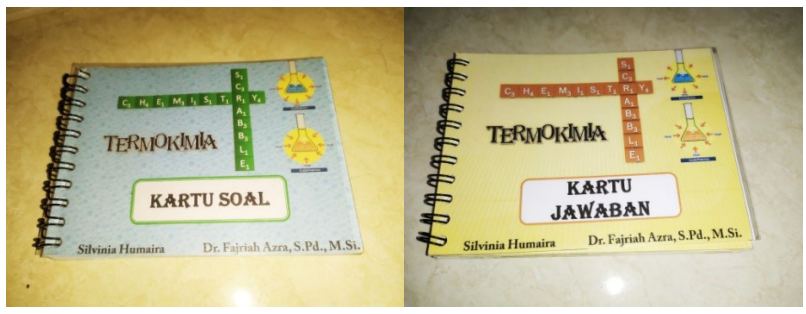

Gambar 2. Kartu Soal dan Kartu Jawaban Permainan Scrabble Kimia.

disajikan pada Gambar 3.

Rak kepingan terbuat dari kayu dengan model bertingkat yang berfungsi untuk meletakkan kepingan huruf yang dimiliki masing-masing pemain. Rak kepingan disajikan pada Gambar 4. Kantong kepingan huruf berfungsi untuk

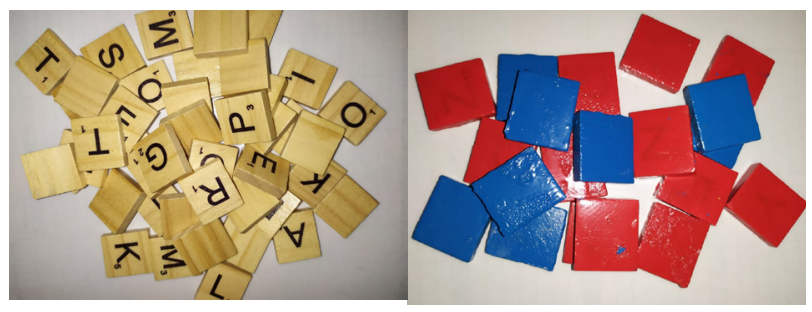

Gambar 3. Kepingan Huruf Permainan Scrabble Kimia.
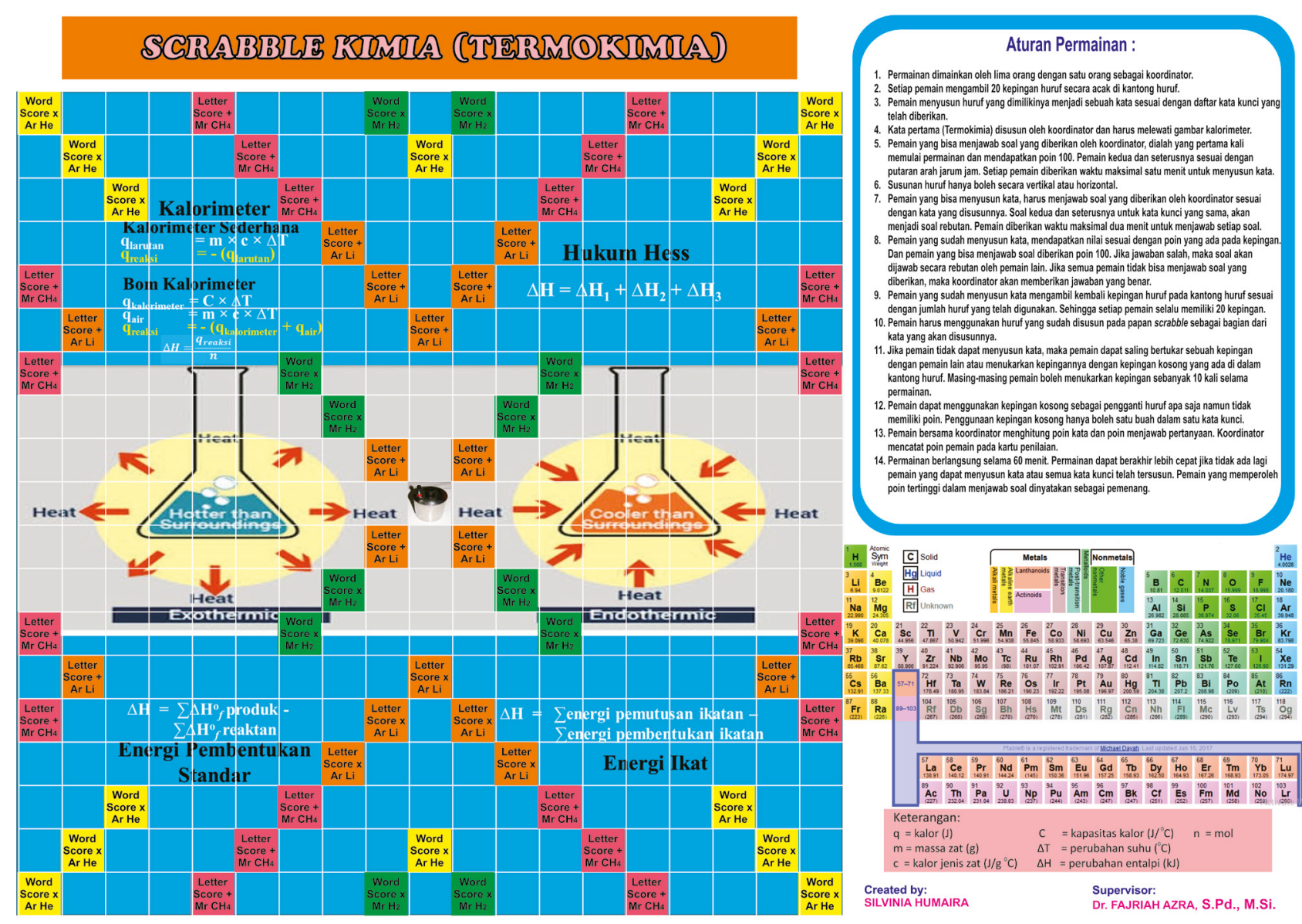

Gambar 1. Papan Permainan Scrabble Kimia. 


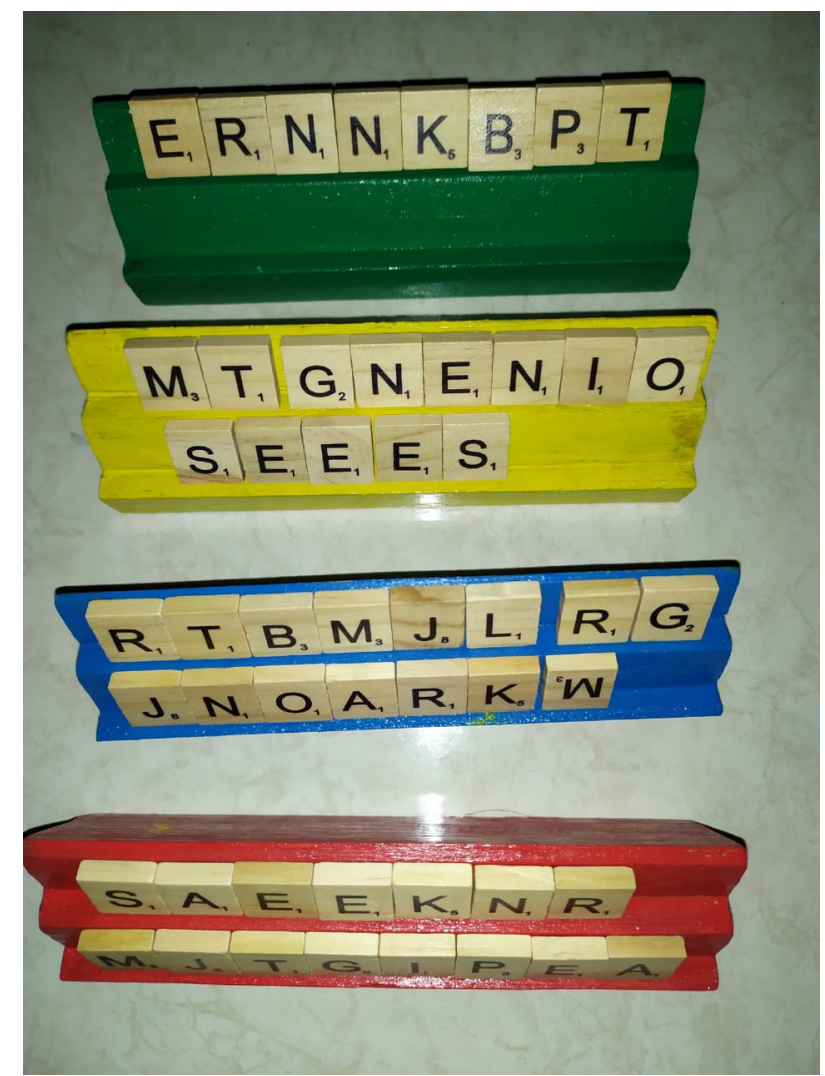

Gambar 4. Rak Kepingan Permainan Scrabble Kimia.

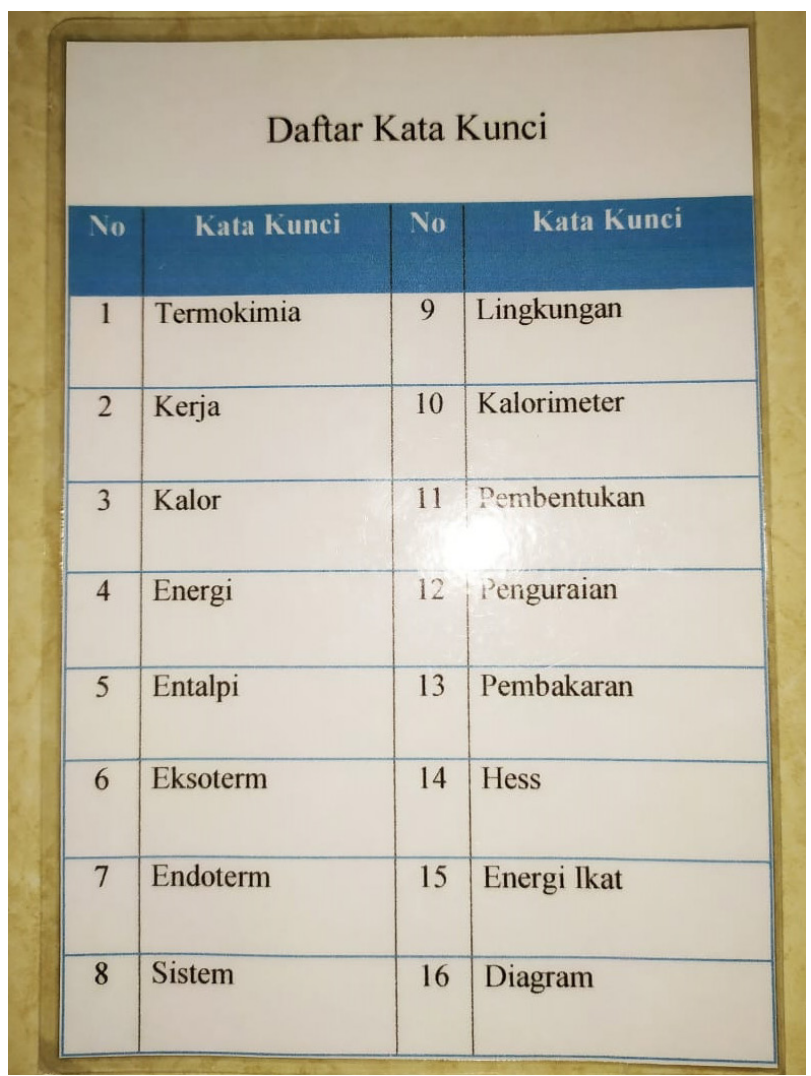

Gambar 5. Daftar Kata Kunci Permainan Scrabble Kimia. menyimpan kepingan huruf.

\subsubsection{Daftar Kata Kunci Permainan Scrabble Kimia.}

Daftar kata kunci disusun berdasarkan konsepkonsep yang terdapat pada materi termokimia. Daftar kata Kunci merupakan acuan dalam menyusun kata. Daftar kata kunci disajikan pada Gambar 5.

\subsection{Tahap Develop (Pengembangan)}

\subsubsection{Uji Validitas}

Uji validitas permainan scrabble kimia dilakukan oleh lima orang pakar, yaitu dua orang dosen kimia Universitas Negeri Padang dan tiga orang guru kimia SMA/MA. Validasi media didasari oleh empat fungsi media, yaitu fungsi kognitif, fungsi afektif, fungsi atensi, dan fungsi kompensatoris ${ }^{[11]}$. Hasil uji validitas permainan scrabble kimia mendapatkan indeks kesepakatan validator sebesar 0,81 dengan kategori valid. Artinya, media permainan scrabble kimia yang dikembangkan telah memenuhi fungsi sebagai media pembelajaran. Sejalan dengan pendapat ${ }^{[12]}$ bahwa suatu produk (media pembelajaran) dikatakan valid apabila mampu mengukur yang seharusnya diukur. Hasil uji validitas media disajikan pada Gambar 6.

Fungsi kognitif media yaitu bagaimana media tersebut dapat membantu memperlancar dalam mencapai tujuan pembelajaran serta mengingat dan memahami informasi yang terdapat dalam media tersebut $^{[11]}$. Uji validitas oleh validator terhadap fungsi kognitif media pembelajaran berupa permainan scrabble kimia materi termokimia memperoleh indeks kesepakatan validator sebesar 0,80 dengan kategori valid. Hal ini menyatakan

\section{Hasil \\ Validasi Permainan Scrabble Kimia}

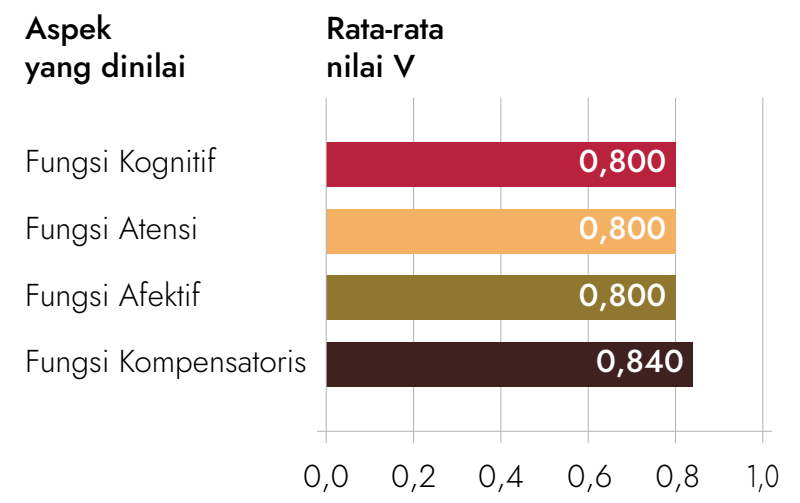

Gambar 6. Hasil Validasi Permainan Scrabble Kimia.

bahwa media permainan scrabble kimia yang dikembangkan dapat membantu mencapai tujuan pembelajaran yaitu dengan bantuan kartu soal dan kartu jawaban yang terdapat pada permainan tersebut.

Fungsi atensi media yaitu bagaimana media tersebut dapat menarik serta mengarahkan perhatian dari peserta didik agar konsentrasi dengan materi pelajaran ${ }^{[11]}$. Uji validitas oleh validator terhadap fungsi atensi media permainan scrabble kimia pada materi termokimia memperoleh indeks kesepakatan validator 0,80 dengan kategori valid. Hal ini menyatakan media permainan scrabble kimia yang telah dikembangkan dapat menarik serta mengarahkan perhatian peserta didik terhadap 


\section{Hasil Uji Praktikalitas Permainan Scrabble Kimia dalam bentuk Tingkat Praktikalitas}

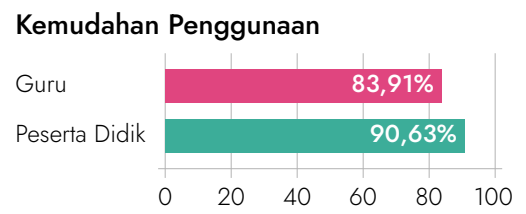

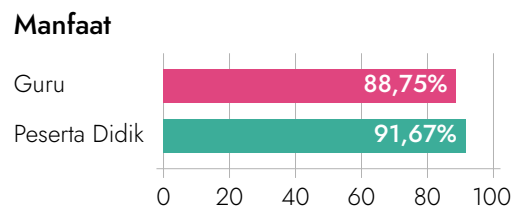

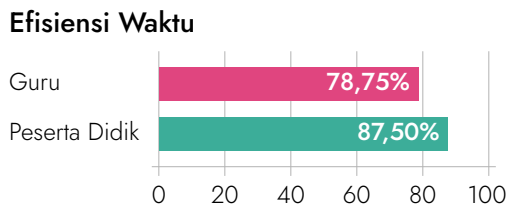

Gambar 7. Hasil Uji Praktikalitas Permainan Scrabble Kimia.

materi termokimia yang dipelajari. Penggunaan bahasa yang baik dan benar, tulisan, simbol, warna, serta gambar yang jelas dan menarik dapat membantu menarik dan mengarahkan peserta didik agar fokus terhadap pembelajaran ${ }^{[13]}$.

Fungsi afektif media yaitu bagaimana media tersebut dapat menggugah emosi serta sikap dari peserta didik terhadap suatu informasi yang ditampilkan yang dilihat dari tingkat kenikmatan peserta didik dalam belajar ${ }^{[1]}$. Pengolahan data penilaian dari validator terhadap fungsi afektif media permainan scrabble kimia sebagai media pembelajaran pada materi termokimia diperoleh indeks kesepakatan validator 0,80 dengan kategori valid, ini menunjukkan bahwa media permainan scrabble kimia pada materi termokimia yang dikembangkan diharapkan dapat membuat peserta didik merasa senang serta terlibat aktif dalam proses pembelajaran khususnya dalam proses pemantapan konsep. Pembelajaran dengan perasaan gembira akan mempercepat proses pembelajaran, kegiatan belajar dapat dioptimalkan, serta dapat menempatkan peserta didik sebagai subjek pendidikan dan akan menghasilkan prestasi belajar ${ }^{[14]}$. Permainan dalam kegiatan belajar mengajar dapat membuat suasana lingkungan belajar menjadi menyenangkan, santai, namun tetap memiliki suasana belajar yang kondusif ${ }^{15]}$.

Fungsi kompensatoris media yaitu bagaimana media tersebut dapat membantu peserta didik yang lemah dalam menerima dan memahami pelajaran yang disajikan dalam bentuk teks atau disajikan secara verbal untuk dapat mengorganisasikan informasi dalam teks, atau mengingat serta mengulangi kembali ${ }^{[11]}$. Hasil olah data penilaian dari validator mengenai fungsi kompensatoris media permainan scrabble kimia sebagai media pembelajaran pada materi termokimia memperoleh indeks kesepakatan validator 0,84 yang memiliki kategori valid, ini menunjukkan bahwa media permainan scrabble kimia yang dikembangkan dapat membantu peserta didik dalam memahami dan memantapkan konsep pada materi termokimia yang dibantu dengan soal-soal latihan, kartu jawaban, dan beberapa rumus pada papan permainan. Penggunaan permainan scrabble kimia tidak terbatas hanya dalam kelas. Permainan scrabble kimia dapat digunakan secara berulang kali dan dapat digunakan di luar kelas, sehingga peserta didik dapat berulang kali melakukan latihan dan memantapkan pemahamannya terhadap materi termokimia.

Setelah dilakukan uji validasi terhadap produk yang telah dikembangkan, maka akan diketahui kelemahannya.Untuk mengurangikelemahan tersebut dilakukan perbaikan sesuai saran dan masukan dari validator sebelum dilakukan uji coba produk.

\subsubsection{Uji Praktikalitas}

Uji praktikalitas media pembelajaran berupa permainan scrabble kimia materi termokimia dilakukan terhadap guru serta peserta didik. Penentuan tingkat praktikalitas bertujuan untuk mengetahui keefektifan dan keefisienan produk yang dihasilkan ${ }^{[7]}$. Media dikatakan praktis apabila media itu telah tersedia, tidak mahal, mudah didapat, mudah digunakan, tidak perlu pelatihan khusus, serta dimengerti guru ${ }^{[13]}$. Penentuan tingkat praktikalitas scrabble kimia pada materi termokimia dilakukan oleh dua orang guru kimia dan 20 orang peserta didik kelas XII IPA dengan cara menyebarkan angket praktikalitas kepada masingmasing responden.

Penilaian praktikalitas didasarkan atas aspek kemudahan penggunaan, manfaat, dan efisiensi waktu dari permainan scrabble kimia yang dikembangkan. Hasil pengolahan data praktikalitas permainan scrabble kimia oleh guru memperoleh nilai praktikalitas produk $89,93 \%$ yang memiliki kategori sangat praktis dan oleh peserta didik memperoleh nilai praktikalitas produk 83,80\% dengan kategori sangat praktis. Artinya, media permainan scrabble kimia yang telah dikembangkan telah memenuhi ciri media praktis. Hasil uji praktikalitas media disajikan pada Gambar 7.

\section{SIMPULAN}

Media pembelajaran berupa permainan scrabble kimia materi termokimia dapat dikembangkan dengan menggunakan model 4-D. Media pembelajaran berupa permainan scrabble kimia materi termokimia yang dikembangkan memiliki tingkat validitas dengan kategori valid berdasarkan fungsi media dan praktikalitas dengan kategori sangat praktis berdasarkan ciri media praktis.

\section{REFERENSI}

1. Hamalik O. Kurikulum dan Pembelajaran.

Jakarta: Bumi Aksara; 2014.

2. Smaldino ES, Lowther DL, Russel DD. Instructional Technology and Media for Learning. USA; 2012.

3. Prayitno E. Psikologi Perkembangan Remaja. Padang: Angkasa Raya; 2006.

4. Corona F, Cozzarelli C, Palumbo C. Information Technology and Edutainment: Education and Entertainment in the Age of Interactivity. Int J Digit Lit Digit Competence. 2013;4(1).

5. Sadiman AS, Rahardjo R, Haryono A, 
Rahardjito D. Media Pendidikan: Pengertian, Pengembangan dan Pemanfaatannya. Depok: Rajawali Pers; 2012.

6. Whisenand TG, Dunphy SM. Accelerating Student Learning of Technology Terms: The Crossword Puzzle Exercise. 2006;21(2):141-9.

7. Sugiyono. Metode Penelitian Pendidikan. Bandung: CV. Alfabeta; 2010.

8. Trianto. Mendesain Model Pembelajaran Inovatif Progresif. Jakarta: Kencana Media Group; 2012.

9. Aiken LR. Content Validity and Reability of single items or questionnaires. Educ Psychol Meas. 1980;40(4):955-9.

10. Riduwan. Belajar Mudah Penelitian untuk Guru-Karyawan dan Peneliti Pemula. Bandung: Alfabeta; 2009.

11. Arsyad A. Media Pembelajaran. Jakarta: Raja Grafindo Persada; 2009.

12. Sukardi. Metodologi Penelitian Pendidikan. Jakarta: Bumi Aksara; 2009.

13. Daryanto. Media Pembelajaran. Yogyakarta: Gava Media; 2010.

14. Chairiah, Sialahi A, Hutabarat W. Pengembangan Bahan Ajar Kimia Materi Larutan Asam dan Basa Berbasis Chemo Edutainment Untuk Siswa SMK TI Kelas XI. J Pendidikan Kimia. 2016;

15. Latuheru J. Media Pembelajaran dalam Proses Belajar-Mengajar Masa Kini. Jakarta: Departemen Pendidikan dan Kebudayaan; 1988. 